\title{
Amomum cardamomum L. ethyl acetate fraction protects against carbon tetrachloride-induced liver injury via an antioxidant mechanism in rats
}

Dong-Woo Lim', Hyuck Kim², Ju-Yeon Park ${ }^{3}$, Jai-Eun Kim, Jin-Young Moon ${ }^{3}$, Sun-Dong Park ${ }^{4}$ and Won-Hwan Park²*

\begin{abstract}
Background: Medicinal herb-derived drug development has become important in the relief of liver pathology. Amomun cardamomum is traditionally used therapeutically in Korea to treat various human ailments including dyspepsia, hiccupping, and vomiting. We investigated to assess the protective effect of $A$. cardamomum on carbon tetrachloride $\left(\mathrm{CCl}_{4}\right.$ )-induced liver damage through antioxidant activity in hepatic tissues of Sprague-Dawley rats.

Methods: Antioxidant properties of different fractions from A. cardamomum from ethanol extracts were evaluated by an in vitro free radical scavenging systems. The protective effect of the ethyl acetate fraction from $A$. cardamomum (EAAC) against $\mathrm{CCl}_{4}$-induced cytotoxicity was determined by a cell viability assay using HepG2 hepatocarcinoma cells. In vivo study, the influence of EAAC concentrations of 100 and $200 \mathrm{mg} / \mathrm{kg}$ following $\mathrm{CCl}_{4}$-induced hepatic injury was assessed. Serum levels of glutamic oxaloacetic transaminase (GOT), glutamic pyruvic transaminase (GPT), and alkaline phosphatase (ALP) were determined, as was lipid peroxidation (malondialdehyde, MDA). Effect of EAAC on liver detoxification enzymes including superoxide dismutase (SOD), total glutathione (GSH), and glutathione S-transferase (GST) activity was measured in rat liver homogenates. Liver cytochrome P450 (CYP2E1) expression level was determined by quantification of mRNA.
\end{abstract}

Results: Phytochemical analysis of A. cardamomum indicated that EAAC was enriched in total polyphenol and total flavonoid. Most of the tannins were confined to the hexane fraction. Hepatoprotective properties of EAAC were evident, with significantly reduced serum levels of GOT, GPT, and ALP compared with the control group. Improved hepatic antioxidant status was evident by increased SOD, GSH, and GST enzymes in rat liver tissue. Liver lipid peroxidation induced by $\mathrm{CCl}_{4}$ was apparent by increased intracellular MDA level. EAAC suppressed lipid peroxidation as evidenced by the significant decrease in MDA production. Expression of CYP2E1 was also significantly decreased at the higher concentration of EAAC, indicating the hepatoprotective efficacy of EAAC on acute liver damage.

Conclusion: These results indicated that EAAC has a significant hepatoprotective activity on $\mathrm{CCl}_{4}$-induced acute hepatic injury in rats, which might be derived from its antioxidant properties and CYP2E1 downregulation.

Keywords: Amomum cardamomum, Carbon tetrachloride, Oxidative stress, Hepatic injury, Antioxidant property

\footnotetext{
* Correspondence: diapwh@dongguk.ac.kr

${ }^{2}$ Department of Diagnostics, College of Korean Medicine, Dongguk

University, Dongguk-Ro 32, Goyang 10326, Republic of Korea

Full list of author information is available at the end of the article
} 


\section{Background}

The liver is crucial in metabolizing xenobiotics through various mechanisms that involve numerous detoxification enzymes and antioxidant activity. Accordingly, the liver is continuously exposed to harmful oxidative stresses that impair cell function, which trigger several liver diseases [1,2]. Liver diseases remained a major global health burdens and medical issue [3]. Oxidative stress is defined as an imbalance between the systemic manifestation of reactive oxygen species (ROS) and the antioxidant defenses [4]. Oxidative stress is crucial in the pathogenesis of liver diseases including fibrosis and liver cirrhosis [5-9]. ROS are chemically reactive molecules containing oxygen that normally function in cellular responses in signal transduction to sustain life and as part of host defenses against various infections [10]. However, excessive production of free radicals including superoxide, hydroxyl radical, lipid free radical, and nitric oxide leads to damage in certain diseases of the liver [11]. Inhibition of free radicals has been linked to the alleviation of liver disorders [12].

Carbon tetrachloride $\left(\mathrm{CCl}_{4}\right)$ can induce free radical toxicity and has been used as a hepatotoxin in diverse liver disease models $[13,14]$. $\mathrm{CCl}_{4}$ is converted into reactants through the formation of reactive intermediates including trichloromethyl radicals $\left(\mathrm{CCl}_{3}, \mathrm{CCl}_{3} \mathrm{OO} \cdot\right)$ and free radicals by cytochrome P450 (CYP 450) [15]. These free radicals and related oxidative stresses induce the deformation of cellular macromolecules, and increases lipid peroxidation, protein degeneration, and genomic mutations in human liver tissue [16]. A member of the CYP family, CYP2E1, is involved in these reactions and in the metabolism of xenobiotics like ethanol. CYP2E1 is regulated by endogenous factors and foreign compounds $[17,18]$. Suppression of CYP2E1 has reduced liver damage in various experimental models including in vitro and in vivo systems [19-21].

The side effects of modern synthetic drugs used to treat liver diseases remains unclear. Traditional medicines and plant-derived drugs might be an attractive alternative in the prevention and treatment of hepatic disorders [12, 22]. Amomum cardamomum L., a member of Zingiberaceae family, can be distinguished from large cardamom native to southern India and is nowadays cultivated widely in tropical regions. The plant seeds are widely used as a spice in many countries and traditionally as a therapeutic for relief of dyspepsia, hiccupping, vomiting, and alcohol detoxification [23]. The previous studies have reported that seed of A. cardamomum and its active components had antioxidant and antiinflammatory activities [24, 25]. Important essential oils constituents including terpenes have been reported in this plant [26]. Another reports suggest that essential oils treatment containing $\alpha, \beta$-pinene, $\mathrm{d}$-camphor, and 1,8-cineole inhibited liver injury in animal models [2729]. 1,8-Cineole, the bicyclic monoterpene rich in A. cardamomum has been reported to have protective bioactivity on liver against steatosis, and 2,3,7,8-tetrachlorodibenzo- $p$-dioxin (TCDD) in vivo [30, 31]. Another study revealed relation between antioxidant activity and hepatoprotection [32,33] which suggests potential effect of $A$. cardamomum on the liver disease related to free radical and other ROS production. The effects of $A$. cardamomum and its fractions on attenuating $\mathrm{CCl}_{4}$-induced hepatotoxicity are unknown, with no study of the involvement of antioxidant activity in vitro and in vivo.

Therefore, in this study we evaluated the possible antioxidant properties and hepatoprotective effects of the ethyl acetate fraction obtained from $A$. cardamomum (EAAC) against $\mathrm{CCl}_{4}$-induced hepatic injury in vitro and in vivo. Furthermore, CYP2E1 gene expression level was investigated to demonstrate the downregulating activity of the EAAC; results were compared to the effects of silymarin, a drug commonly used as a liver therapeutic agent.

\section{Methods}

\section{Chemicals}

2.2-Diphenyl-1-picryl hydrazyl (DPPH), butylated hydroxytoluene $(\mathrm{BHT}), \mathrm{d}(+)$-catechin, gallic acid, tannic acid, sodium carbonate, nitrobluetetrazolium (NBT), xanthine, xanthine oxidase, and Folin-Ciocalteu reagent, iron(III) chloride $\left(\mathrm{FeCl}_{3}\right)$, hydrogen peroxide $\left(\mathrm{H}_{2} \mathrm{O}_{2}\right)$, ascorbic acid were all purchased from Sigma-Aldrich (St. Louis, MO, USA) or Merck \& Co (Darmstadt, Germany). For in vitro studies, bovine serum albumin, Dulbecco's Modified Eagle Medium (DMEM), fetal bovine serum (FBS), Dulbecco's phosphate buffered saline (DPBS), penicillin, and streptomycin were purchased from Hyclone (Logan, UT, USA). Oligo primers were purchased from Macrogen (Seoul, Korea). For in vivo studies, silymarin, olive oil, $\mathrm{CCl}_{4}$, Oil Red $\mathrm{O}$, hematoxylin and eosin (H\&E) stain, triethanolamide, 5,5'-dithiobis(2-nitrobenzoic acid) (DTNB), glutathione (GSH), superoxide dismutase (SOD), 2-thiobarbituric acid (TBA), and sodium azide were purchased from Sigma-Aldrich.

\section{A. cardamomum and extraction}

Dried A. cardamomum seeds were purchased from Dongwoodang (Yeongcheon-si, Korea). The seeds were ground finely using a mixer grinder and the resulting powder was extracted by a 3-day immersion in $70 \%$ ethanol. The extract was evaporated using a rotary evaporator (Büchi, Flawil, Switzerland) prior to sequential fractionation using hexane, dichloromethane, and ethyl acetate applied with an extraction funnel. Each fraction 
was concentrated and dried using the aforementioned rotary evaporator. The extract was harvested and used as samples.

\section{Cell culture and viability assay}

HepG2 human liver carcinoma cells were cultured in DMEM supplemented with $10 \% \mathrm{FBS}, 100 \mathrm{U} / \mathrm{ml}$ penicillin and streptomycin. Cells were incubated at $37^{\circ} \mathrm{C}$ in a humidified environment containing $5 \% \mathrm{CO}_{2}$. Cells were subcultured at 70-80\% confluence and seeded at a density of $1 \times 10^{5}$ cells/well in 96-well plates. After $24 \mathrm{~h}$, the medium changed to FBS-free DMEM. After $24 \mathrm{~h}$ pretreatment of EAAC samples (dissolved in DMSO), the medium was changed to DMEM containing $8 \mathrm{mM} \mathrm{CCl}_{4}$. The cells were incubated in $37{ }^{\circ} \mathrm{C}$ in the humidified $\mathrm{CO}_{2}$ incubator for $2 \mathrm{~h}$ followed by cell viability determined using the EZ-Cytox cell viability assay kit (Daeil Lab Service, Seoul, Korea) as described by the manufacturer. Briefly, $10 \mu \mathrm{l}$ of the EZ-Cytox reagent was added to each culture well of a 96-well microplate and incubated at $37{ }^{\circ} \mathrm{C}$ in the humidified $\mathrm{CO}_{2}$ incubator for $2 \mathrm{~h}$. After incubation, optical density (OD) of the supernatant was measured at a wavelength of $450 \mathrm{~nm}$ using a microplate reader.

\section{Determination of total phenolic, flavonoids and tannins Tannin content}

Tannin content was measured using the Folin-Denis method [34]. Fifty microliters of extract was made up to $7.5 \mathrm{ml}$ by the addition of distilled water. Then, $0.5 \mathrm{ml}$ of Folin Denis reagent and $1 \mathrm{ml}$ of $\mathrm{Na}_{2} \mathrm{CO}_{3}$ were added and mixed. The volume was made up to $10 \mathrm{ml}$ using distilled water. The absorption was recorded at $700 \mathrm{~nm}$. Tannic acid and distilled water was used as standard and blank, respectively.

\section{Phenol content}

Phenol content was measured by the Folin-Ciocalteu method [35]. A sample aliquot $40 \mu \mathrm{l}$ was added to $200 \mu \mathrm{l}$ of Folin-Ciocalteu reagent along with $1160 \mu \mathrm{l}$ of distilled water and mixed. The mixture was incubated for $3 \mathrm{~min}$ at room temperature prior to the addition of $600 \mu \mathrm{l}$ of $2 \%$ sodium carbonate. After $2 \mathrm{~h}$ incubation in the dark, the mixture was aliquoted into wells of a 96 well plate and the OD was measured at $765 \mathrm{~nm}$. Gallic acid and distilled water was used as standard and blank, respectively.

\section{Flavonoid content}

Total flavonoid content for samples was determined by the aluminium chloride colorimetric method [36] with slight modification. $1 \mathrm{ml}$ of water was added to $250 \mu \mathrm{l}$ samples in a tube. At zero time, $75 \mu \mathrm{l}$ of $5 \% \mathrm{NaNO}_{2}$ was added to the tube. After $5 \mathrm{~min}, 0.3 \mathrm{ml}$ of $10 \% \mathrm{AlCl}_{3}$ was added and incubated for $6 \mathrm{~min}$. After, $0.5 \mathrm{ml}$ of $1 \mathrm{M}$ $\mathrm{NaOH}$ was added to the mixture. Absorbance was read at $510 \mathrm{~nm}$ with water as the blank. Various concentrations of $(+)$ catechin hydrate solution was used as standard.

\section{In vitro antioxidant properties}

To determine free radical scavenging activities of sample, $40 \mu \mathrm{l}$ of various concentrations of sample was added to $760 \mu \mathrm{l}$ solution of $0.3 \mathrm{mM}$ DPPH dissolved in ethanol. An equal amount of ethanol and DPPH served as control. After 30 min incubation in the dark, the absorbance was recorded at $517 \mathrm{~nm}$. The experiment was performed in triplicate and the activity was presented as percentage of scavenged radical. To determine superoxide anion scavenging activities of sample a slight modification of a prior protocol was used [37]. In brief, each sample was mixed with $30 \mathrm{mM}$ EDTA (pH 7.4), $3 \mathrm{mM}$ hypoxanthine in $50 \mathrm{mM}$ sodium peroxide, and $1.42 \mathrm{mM} \mathrm{NBT}$. The mixture was incubated for $3 \mathrm{~min}$ at room temperature following the addition of xanthine oxidase and increased volume to to $3 \mathrm{ml}$ with phosphate buffer ( $\mathrm{pH} 7.4$ ). The mixture was incubated for $20 \mathrm{~min}$ at room temperature and absorbance at $560 \mathrm{~nm}$ was measured using a spectrophotometer. To determine hydroxyl radical scavenging activity, cloned pBR322 plasmid DNA from transformed bacteria was used in assay. Supercoiled (SC) pBR322 plasmid DNA $(2.0 \mu \mathrm{g})$ was mixed with various concentrations of EAAC. The fenton's reagent $(80 \mu \mathrm{M}$ $\mathrm{FeCl}_{3}, 0.3 \mathrm{mM} \mathrm{H}_{2} \mathrm{O}_{2}, 50 \mu \mathrm{M}$ ascorbic acid) was added to samples and volume brought up to $20 \mu$ l. The mixture was incubated at $37{ }^{\circ} \mathrm{C}$ for $30 \mathrm{~min}$. Samples were loaded into agarose gel and photographed under UV illuminator.

\section{Animals and experimental design}

Six-week-old specific pathogen-free male Sprague-Dawley rats $(n=30)$ purchased from Koatech (Gyeonggi-do, Korea) received standard normal diet and water ad libitum. The animals were acclimatized to $12 \mathrm{~h}$ light/dark cycles for 7 days prior to the experiments. They were divided randomly into five groups of six rats: negative control (olive oil; $1 \mathrm{ml} / \mathrm{kg}), \mathrm{CCl}_{4}(1 \mathrm{ml} / \mathrm{kg}$, dissolved $1: 1 \mathrm{in}$ olive oil), $\mathrm{CCl}_{4}+$ Silymarin $(50 \mathrm{mg} / \mathrm{kg}$, dissolved in olive oil), $\mathrm{CCl}_{4}$ + low dose EAAC $(100 \mathrm{mg} / \mathrm{kg}$, dissolved in olive oil), and $\mathrm{CCl}_{4}+$ high dose EAAC $(200 \mathrm{mg} / \mathrm{kg}$, dissolved in olive oil). All treatments were administrated every $72 \mathrm{~h}$ for 5 weeks. Bodyweight was recorded weekly. The day after the final treatment, all animals were starved overnight and sacrificed. Whole blood was collected from the abdominal aorta and the liver was harvested under zoletil anesthesia. All protocols for animal experiments were approved by the ethics committee of Dongguk University (No. 2014-09110). 


\section{Serum biochemistry}

After sacrifice, the collected blood was immediately centrifuged at $3000 \mathrm{rpm}$ for $20 \mathrm{~min}$. The supernatant was stored at $4{ }^{\circ} \mathrm{C}$ until analyses for alanine transaminase (ALT), aspartate transaminase (AST), and alkaline phosphatase (ALP) using commercial kits (Company, Asan, Korea) according to the manufacture's protocols. As well, OD was determined using a spectrophotometer.

\section{Determination of lipid peroxidation}

Lipid peroxidation level of rat liver was assessed by a previously described malondialdehyde (MDA) assay protocol [38] with slight modification. In brief, rats were sacrificed and the liver was isolated after blood perfusion. Liver tissue was homogenized with $1.15 \% \mathrm{KCl}$ (9:1, $\mathrm{w} / \mathrm{w})$. Aliquots $(400 \mu \mathrm{l})$ of homogenate were mixed with TBA to a final concentration of $8.1 \%$. The reactant was heated to $95{ }^{\circ} \mathrm{C}$ for $1 \mathrm{~h}$ prior to the addition of $1 \mathrm{ml}$ of distilled water and a $5 \mathrm{ml}$ solution of $\mathrm{n}$-butanol and pyridine (15:1). The reactant was centrifuged at $3000 \mathrm{rpm}$ for $30 \mathrm{~min}$. The supernatant was transferred to wells of a 96-well plate and the OD was measured at $532 \mathrm{~nm}$. Various concentrations of 1,1,3,3-tetraethoxy propane were used as standard.

\section{Intracellular antioxidant enzymes detection}

Total Sulfhydryl (SH) level of liver tissue was measured using a prior protocol [39]. In brief, $20 \mu \mathrm{l}$ of liver sample or standard was mixed with $75 \mu \mathrm{l}$ of Tris- $\mathrm{HCl}(\mathrm{pH} 8.2)$ and $25 \mu \mathrm{l}$ of DTNB $(3 \mathrm{mM})$ in methanol prior to the addition of $400 \mu \mathrm{l}$ of methanol. Then mixture was spin down at $3000 \mathrm{~g}$ for $5 \mathrm{~min}$ at room temperature. The sample was transferred to well of a microplate and absorbance was read at $412 \mathrm{~nm}$. Different concentrations of GSH were used as standard. The experiments were conducted in triplicate. SOD activity of liver tissue was investigated using NBT [40]. Briefly, $0.1 \mathrm{mM}$ xanthine, $0.1 \mathrm{mM}$ EDTA, and $25 \mathrm{uM}$ NBT were dissolved in 60 uM sodium bicarbonate buffer. Sample and reaction buffer was mixed in a 1:9 (w/w) ratio. SOD was used as standard. One unit of SOD was equivalent to the amount of enzyme that inhibited the rate of the CYPcatalyzed reaction by $50 \%$.

\section{Histology}

Liver tissues were frozen using a frozen section compound (Leica, Jena, Germany) and sectioned using a model CM 1860 cryotome (Leica). Slide sections were fixed with $10 \%$ formaldehyde and deparaffinized and stained with H\&E or Oil Red O stain. Microscopic images were taken under $200 \times$ concentrations using a DFC 480 microscope system (Leica).
Quantitative real-time polymerase chain reaction (RT-PCR) and conventional PCR

A portion of each liver tissue was stored in RNA Later solution (Life Technologies, Carlsbad, CA, USA) at $-80^{\circ}$ $\mathrm{C}$ for investigation of mRNA expression. Liver mRNA was isolated from liver tissues using Trisure (Bioline, Taunton, MA, USA) following the manufacturer's protocol. Isolated mRNA was checked for RNA integrity and cDNA was synthesized. PCR amplification comprised 10 min at $95^{\circ} \mathrm{C}, 45$ denaturation cycles at $95{ }^{\circ} \mathrm{C}$ for $10 \mathrm{~s}$, annealing at $52{ }^{\circ} \mathrm{C}$ for $30 \mathrm{~s}$, and extension at $72{ }^{\circ} \mathrm{C}$ for $15 \mathrm{~s}$. This was followed by melting curve analysis. Every $\mathrm{Ct}$ value and Second Derivative Max quantification was checked. Results were analyzed using Light Cycler software (Roche Applied Science, Basel, Switzerland). Primer sequences used for RT-PCR were as follows: GST sense 5'- GCCTTCTACCCGAAGACACCTT - 3' and antisense 5' - GTCAGCCTGTTCCCTACA - 3', SOD sense 5' AGGCCGTGTGCGTGCTGAG - 3' and antisense 5' - CA CCTTTGCCCAAGTCATCTGC - 3', CYP2E1 sense 5' - A TGTCATCCCCAAGGGTACA - 3' and antisense 5' - A GGCCTTCTCCAACACACAC - 3', GAPDH sense 5' - G GCACAGTCAAGGCTGAGAATG - 3' and GAPDH antisense 5' - ATGGTGGTGAAGACGCCAGTA - 3'.

Conventional PCR for CYP2E1 gene was conducted with 30 amplification cycles of PCR consisting of denaturation at $95{ }^{\circ} \mathrm{C}$ for $1 \mathrm{~min}$, annealing at $52{ }^{\circ} \mathrm{C}$ for $1.5 \mathrm{~min}$, elongation at $72{ }^{\circ} \mathrm{C}$ for $2 \mathrm{~min}$. Equal amount of PCR product was then loaded and performed electrophoresis on $1 \%$ agarose gel for $30 \mathrm{~min}$. The relevant expression level was then visualized by UV illuminator (UVP, Cambridge, UK).

\section{Statistical analyses}

The results are expressed as mean \pm standard deviation (SD). Experimental data were analyzed using Graph Pad prism version 5.0 software (Graph Pad, La Jolla, CA, USA). Standard curves were constructed using Excel and Powerpoint software (Microsoft, Redmond, WA, USA). All samples were compared with a standard graph using analysis of variance and Student's $t$-test. A p-value $<0.05$ was considered statistically significant.

\section{Results}

Phytochemical analysis and antioxidant activity

Among the fractions obtained, EAAC displayed the highest content of polyphenol $(72.32 \pm 1.22 \mathrm{mg} \mathrm{GAE} / \mathrm{g}$ dried extract) and flavonoid (4.03 $\pm 0.05 \mathrm{mg} \mathrm{CE} / \mathrm{g}$ dried extract). Tannins were most abundant in the hexane fraction $(86.12 \pm 3.09 \mathrm{mg} \mathrm{TAE} / \mathrm{g}$ dried extract) followed by the ethyl acetate fraction $(51.52 \pm 3.32 \mathrm{mg} \mathrm{TAE} / \mathrm{g}$ dried extract) (Table 1).

A. cardamomum extracts were fractionated with various solvents. EAAC showed highest efficacy in free 
Table 1 Total phenolic, flavonoid and tannin contents and antioxidatn activity of different extract from Amomum cardamomum L

\begin{tabular}{|c|c|c|c|c|c|}
\hline Extract & $\begin{array}{l}\text { TPC } \\
\text { (mg GAE/g extract) }\end{array}$ & $\begin{array}{l}\text { TFC } \\
\text { (mg CE/g extract) }\end{array}$ & $\begin{array}{l}\text { TTC } \\
\text { (mg TAE/g extract) }\end{array}$ & $\begin{array}{l}\text { DPPH } \\
\mid \mathrm{C}_{50}(\mu \mathrm{g} / \mathrm{ml})\end{array}$ & $\begin{array}{l}\text { NBT } \\
\text { reduction } \\
\mathrm{IC}_{50}(\mu \mathrm{g} / \mathrm{ml})\end{array}$ \\
\hline Aqua & $7.59 \pm 0.73$ & - & $13.91 \pm 2.43$ & - & - \\
\hline Ethanol & $24.49 \pm 0.13$ & $0.42 \pm 0.13$ & $40.78 \pm 0.94$ & $249.77 \pm 8.09$ & - \\
\hline Ethyl acetate & $72.32 \pm 1.22$ & $4.03 \pm 0.05$ & $51.52 \pm 3.32$ & $148.51 \pm 6.51$ & $21.35 \pm 4.94$ \\
\hline Buthanol & $31.83 \pm 0.20$ & $0.42 \pm 0.20$ & $20.70 \pm 6.31$ & $211.05 \pm 2.32$ & - \\
\hline Dichloromethane & $38.64 \pm 1.17$ & $1.62 \pm 0.05$ & $39.81 \pm 1.46$ & $163.31 \pm 8.60$ & $46.15 \pm 5.55$ \\
\hline Hexane & $29.95 \pm 1.12$ & $3.75 \pm 0.28$ & $86.12 \pm 3.09$ & $224.33 \pm 5.01$ & - \\
\hline BHT & - & - & - & $34.78 \pm 2.92$ & - \\
\hline Ascorbic acid & - & - & - & - & $22.02 \pm 3.25$ \\
\hline
\end{tabular}

TPC total phenolic content, TFC total flavonoid content, TTC total tannin content, GAE gallic acid equivalent, CE catechin equivalent, TAE tannic acid equivalent

radical scavenging activity and superoxide anion scavenging activity (Table 1). EAAC also displayed hydroxyl radical scavenging activity. Fenton's reagent fragmented plasmid DNA into small size band (Fig. 1). EAAC displayed a dose-dependent protective effect from hydrogen peroxide.

\section{HepG2 cell proliferation in $\mathrm{CCl}_{4}$-induced hepatotoxicity}

There was no significant toxicity shown by EAAC treatment to HepG2 cell for $24 \mathrm{~h}$ under $100 \mu \mathrm{g} / \mathrm{ml}$ concentration (Fig. 2a). Changing the culture medium to $\mathrm{CCl}_{4}$ ( $8 \mathrm{mM})$ DMEM for $2 \mathrm{~h}$ reduced HepG2 cell viability by 55 \% (Fig. 2b). Silymarin pretreatment successfully increased viability of HepG2 cells. Furthermore, viability of cell populations pretreated with EAAC was enhanced upon $\mathrm{CCl}_{4}$ treatment in a dose dependent manner, with $90 \%$ preservation of viability using $100 \mu \mathrm{g} / \mathrm{ml}$ EAAC.

\section{Liver enzyme activities in rat serum levels}

All serum enzymes of rats regularly injected with $\mathrm{CCl}_{4}$ were significantly increase compared with the normal group. The silymarin group showed significant reductions in serum levels of GPT, GOT, and ALP. Serum GPT activity was also significantly decreased by both concentrations of EAAC, with both results were significant (Fig. 3a; both $p<0.05$ ). Serum GOT level was significantly decreased in the EAAC $200 \mathrm{mg} / \mathrm{kg}$ group $(p<0.01)$ but not in the $100 \mathrm{mg} / \mathrm{kg}$ group (Fig. 3b).
Serum ALP levels were markedly decreased by EAAC $200 \mathrm{mg} / \mathrm{kg}$ administration (Fig. 3c; $p<0.05$ ).

\section{Histological assessment of liver tissues}

Livers were isolated from rats after sacrifice. H\&E staining of liver sections of each group revealed severely damage by $\mathrm{CCl}_{4}$ injection in tissue around the hepatic vein (Fig. 4a). Silymarin treatment resulted in relatively less necrosis and liver tissue collapse. Both concentrations of EAAC ameliorated hepatic damage induced by $\mathrm{CCl}_{4}$. Oil red $\mathrm{O}(\mathrm{ORO})$ staining of liver section is presenting lipid accumulation caused by $\mathrm{CCl}_{4}$. The ORO stain appeared in lesser portion of liver section in EAAC $200 \mathrm{mg} / \mathrm{kg}$ and silymarin groups compared with $\mathrm{CCl}_{4}$ group.

\section{Reduction of lipid peroxidation}

To investigate the effect of EAAC administration on lipid peroxidation, a MDA assay was carried out with liver tissue of each group. $\mathrm{CCl}_{4}$ injection induced the accumulation of lipid in liver, thus producing peroxidation product (Fig. 5). Silymarin treatment significantly reduced the products of lipid peroxidation. EAAC administration decreased amount of lipid peroxidation contents in liver tissue in a dose-dependent manner. Administration of EAAC $200 \mathrm{mg} / \mathrm{kg}$ significantly decreased MDA product $(p<0.01)$, but EAAC $100 \mathrm{mg} / \mathrm{kg}$ did not.

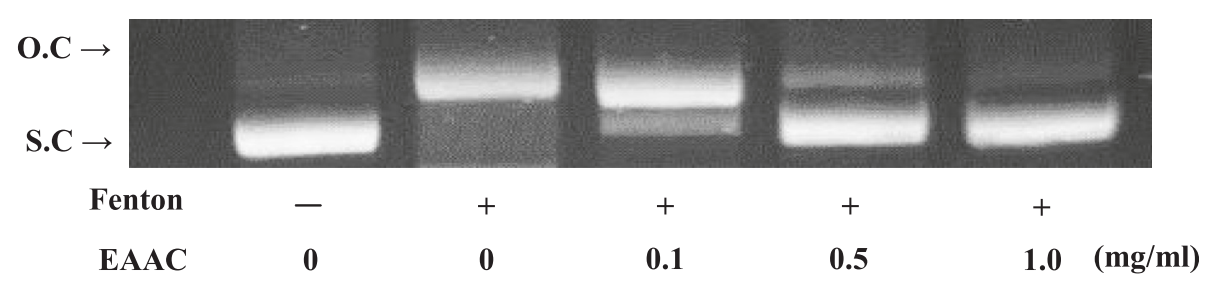

Fig. 1 Anti-oxidative activities of ethyl acetate fractions from Amomum cardamomum (EAAC) determined by hydroxyl radical assay. The result of DNA nicking assay for hydroxyl radical scavanging activity was illuminated by checking DNA on gel electrophoresis. O.C Open cicular DNA nick form, S.C Super coil plamid DNA 

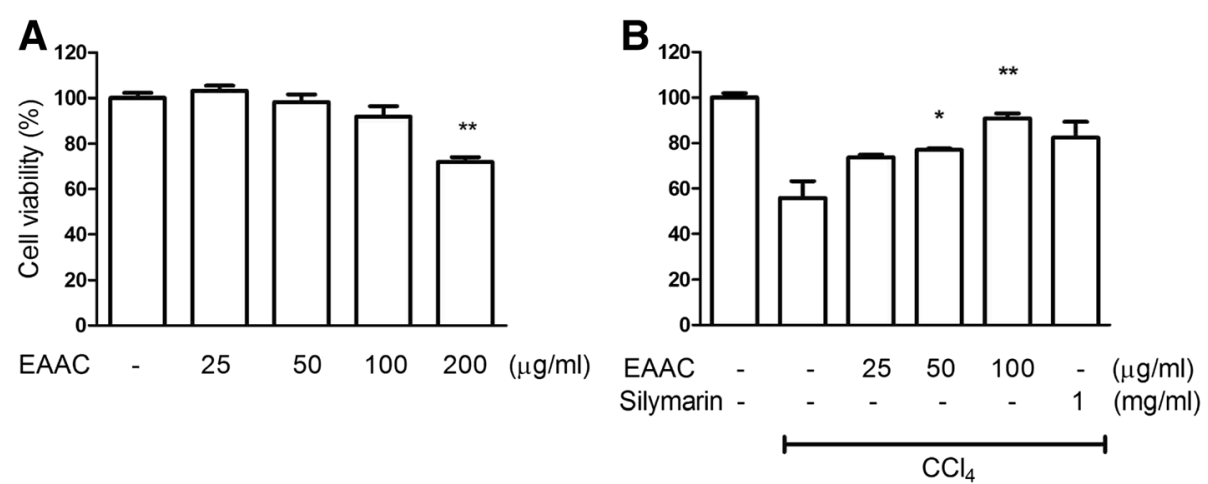

Fig. 2 Hepatoprotective effect of EAAC was assessed in vitro. a HepG2 Cell viability with different concentrations of EAAC was determined after $24 \mathrm{~h}$ incubation. b Recovered HepG2 cell viability against $\mathrm{CCl}_{4}$ by treatment of different concentrations of EAAC and silymarin. The culture media changed with FBS-free DMEM containing $\mathrm{CCl}_{4}(8 \mathrm{mM})$ for $2 \mathrm{~h} .{ }^{*}$ shows statistically significant differences at $p<0.05$ from the $\mathrm{CCl}_{4}$ group and ${ }^{* *}$ at $p<0.01$

\section{Detoxification of $\mathrm{CCl}_{4}$-induced liver damage}

As toxicity induced by $\mathrm{CCl}_{4}$ was attenuated by EAAC administration, the concentration of liver detoxification enzyme was investigated. The EAAC effect on total sulfhydryl (SH) and SOD activities was assessed (Figs. 6a and b). $\mathrm{CCl}_{4}$ injection significantly reduced total $\mathrm{SH}$ and SOD activities. Silymarin treatment successfully recovered both enzyme levels to almost the normal levels $(p<0.05)$. However, there was a notable increase in both total SH and SOD activities by both concentrations of EAAC $(p<0.05)$. Gene expression levels of GST and
SOD in the liver were assessed with real-time quantitative PCR. GST and SOD expression was suppressed by $\mathrm{CCl}_{4}$ injection, but was significantly escalated in rats treated with silymarin EAAC $200 \mathrm{mg} / \mathrm{kg}$ (Fig. 6c, d; $p<$ $0.05)$.

\section{Reduction of CYP2E1 expression levels}

To investigate the mechanism related with the effect of EAAC treatment, we performed real time quantitative PCR. $\mathrm{CCl}_{4}$ injection increased CYP2E1 gene expression by $101 \%$ compared with the normal group. Silymarin
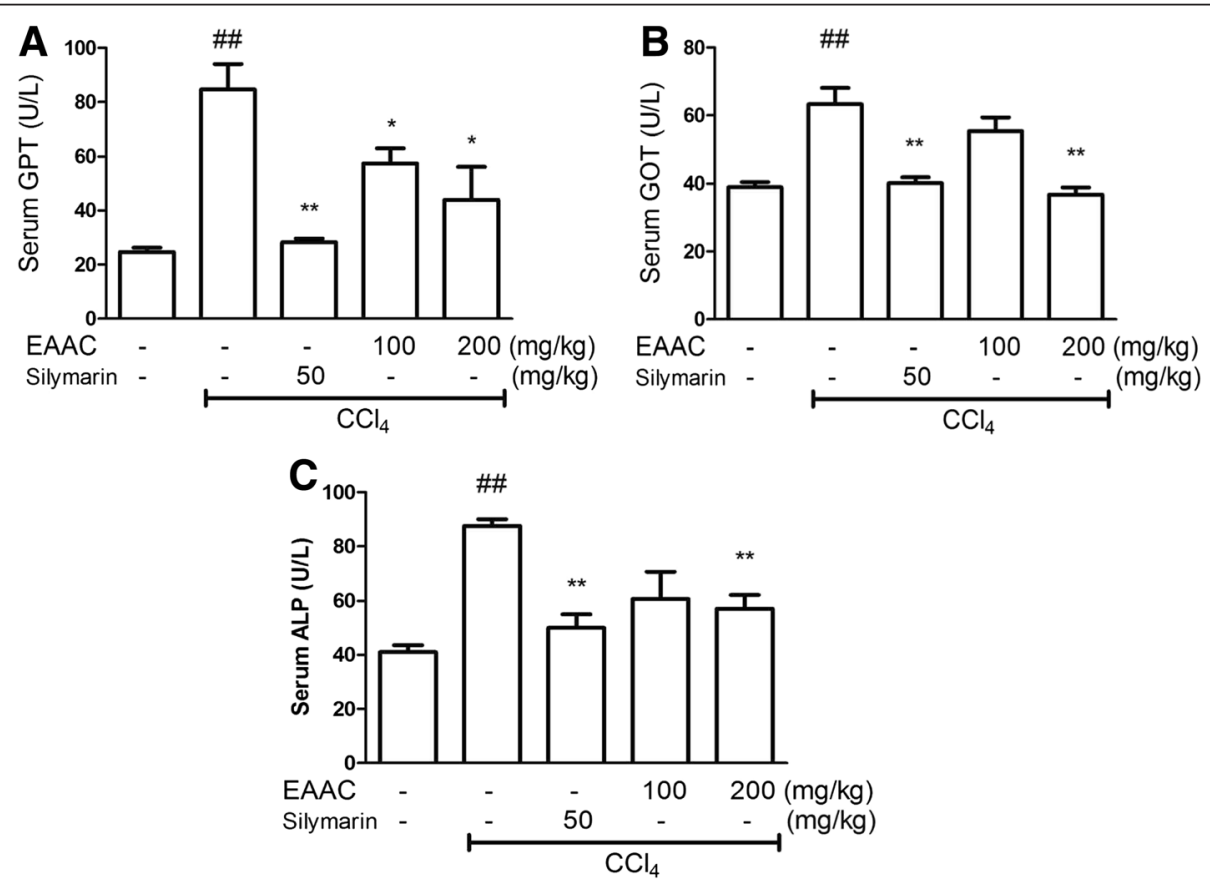

Fig. 3 Effect of EAAC on various liver enzyme levels of serum from SD rat in vivo study. a GPT enzyme concentration, (b) GOT enzyme concentration, (c) ALP enzyme concentration were represented as international unit $(\mathrm{U} / \mathrm{L})$. ${ }^{\#}$ shows statistically significnat difference at $p<0.01$ from the untreated group. * shows statistically significant differences at $p<0.05$ from the $\mathrm{CCl}_{4}$ group and ** at $p<0.01$ 


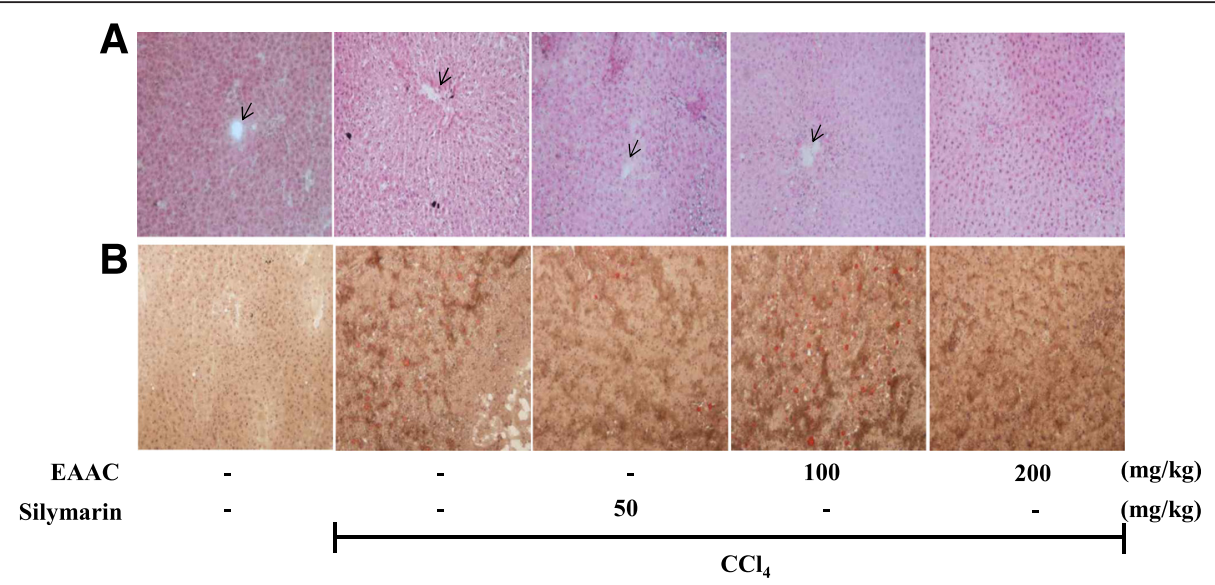

Fig. 4 a. Hematoxylin-eosin (H\&E) stained and (b). Oil Red O (ORO) stained sections of liver tissues from SD rat in vivo study. Normal group, $C C{ }_{4}$ $(1 \mathrm{~mL} / \mathrm{kg})$ treated group, Silymarin $(50 \mathrm{mg} / \mathrm{kg})+\mathrm{CCl}_{4}$ treated group, EAAC $(100 \mathrm{mg} / \mathrm{kg})+\mathrm{CCl} 4$ group and EAAC $(200 \mathrm{mg} / \mathrm{kg})+\mathrm{CCl} \mathrm{group} \mathrm{from}_{4}$ left to right. Pictures were taken by microscope under 200x magnification. Pictures show nearby area of central vein (arrow head)

treatment reduced this increment significantly $(p<0.01)$. Treatment with EAAC $100 \mathrm{mg} / \mathrm{kg}$ produced no significant difference, but whereas the $200 \mathrm{mg} / \mathrm{kg}$ concentration significantly reduced CYP2E1 expression (Fig. 7; $p$ $<0.01)$. This was also supported by similar result of conventional PCR product loaded on agarose gel (Fig. 7, upper panel).

\section{Discussion}

The data presented in this study demonstrate that $A$. cardamomum protects against $\mathrm{CCl}_{4}$-induced acute liver injury. $\mathrm{CCl}_{4}$ is an extensively studied hepatotoxin that is converted $\mathrm{CCl}_{3}$ including trichloromethyl $\left(\mathrm{CCl}_{3}, \mathrm{CCl}_{3} \mathrm{OO} \cdot\right)$ free radicals [15]. Free radical and

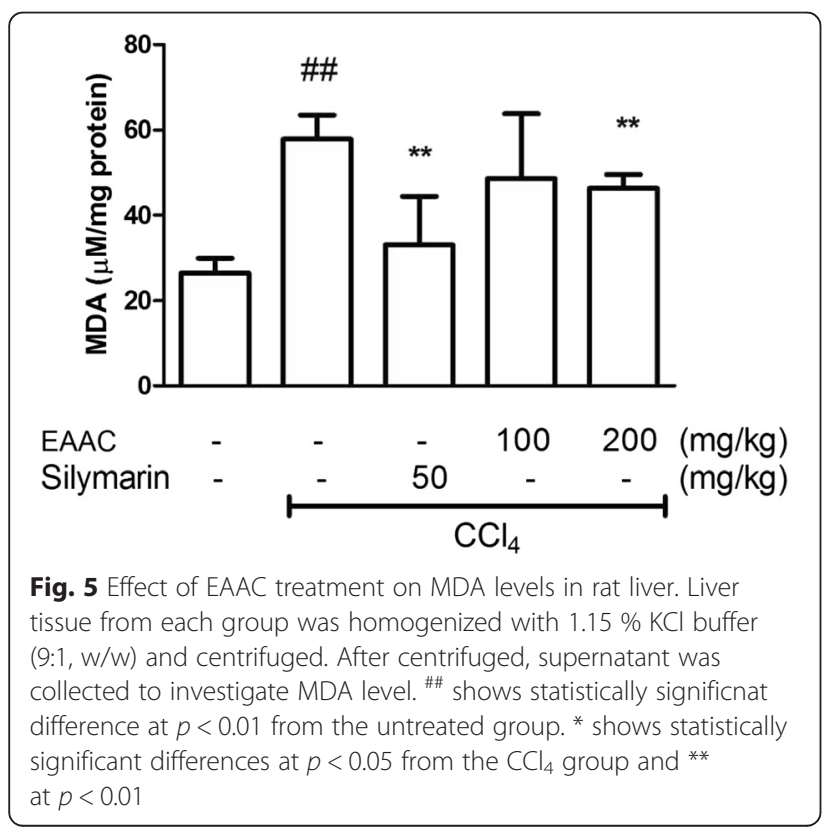

oxidative stresses have been associated with numerous liver diseases, such as cirrhosis, genotoxicity of hepatic tissue, and hepatic carcinoma [1, 41]. Several endogenous enzymatic and non-enzymatic systems are needed to protect the liver from free radicals [42]. Natural plant-derived antioxidants protect cellular detoxification systems from the harmful responses of excessive oxidation converted free radicals from $\mathrm{CCl}_{4}$ $[20,43]$.

The antioxidant properties of the A. cardamomum ethanol extract and organic fractions were tested using various in vitro systems. Especially, the ethyl acetate fraction from A. cardamomum (EAAC) strongly inhibited formation of DPPH free radicals, superoxide anions, and hydroxyl radicals. The relatively high antioxidant capacity was attributable to the abundance of polyphenol and flavonoid compounds in ethyl acetate fraction from crude extract of natural plants. Similarly, a recent study [44] found that the ethyl acetate fraction of Crescentia cuhete leaves and stem bark possess a stronger antioxidant capacity than other fractions in a rapid in vitro assay. It is clear that ethyl acetate fractions from natural plants that contain phenolic compounds and flavonoids have superior antioxidant properties. In addition, the treatment of HepG2 hepatocarcinoma cells with $\mathrm{CCl}_{4}$ presently resulted in decreased cell viability. This observation agrees with previous reports using various cancer cell lines $[9,45]$. On the other hand, pretreatment with EAAC significant recovered cell viability, perhaps due to the reduction of cytotoxicity.

Various recent studies have demonstrated that natural plant-derived phytochemicals protect the liver against $\mathrm{CCl}_{4}$-induced damage, such as cirrhosis, steatosis, and hepatic fibrosis $[7,20,46]$. This was presently implied by the significant decreases in serum levels of ALT, AST, 

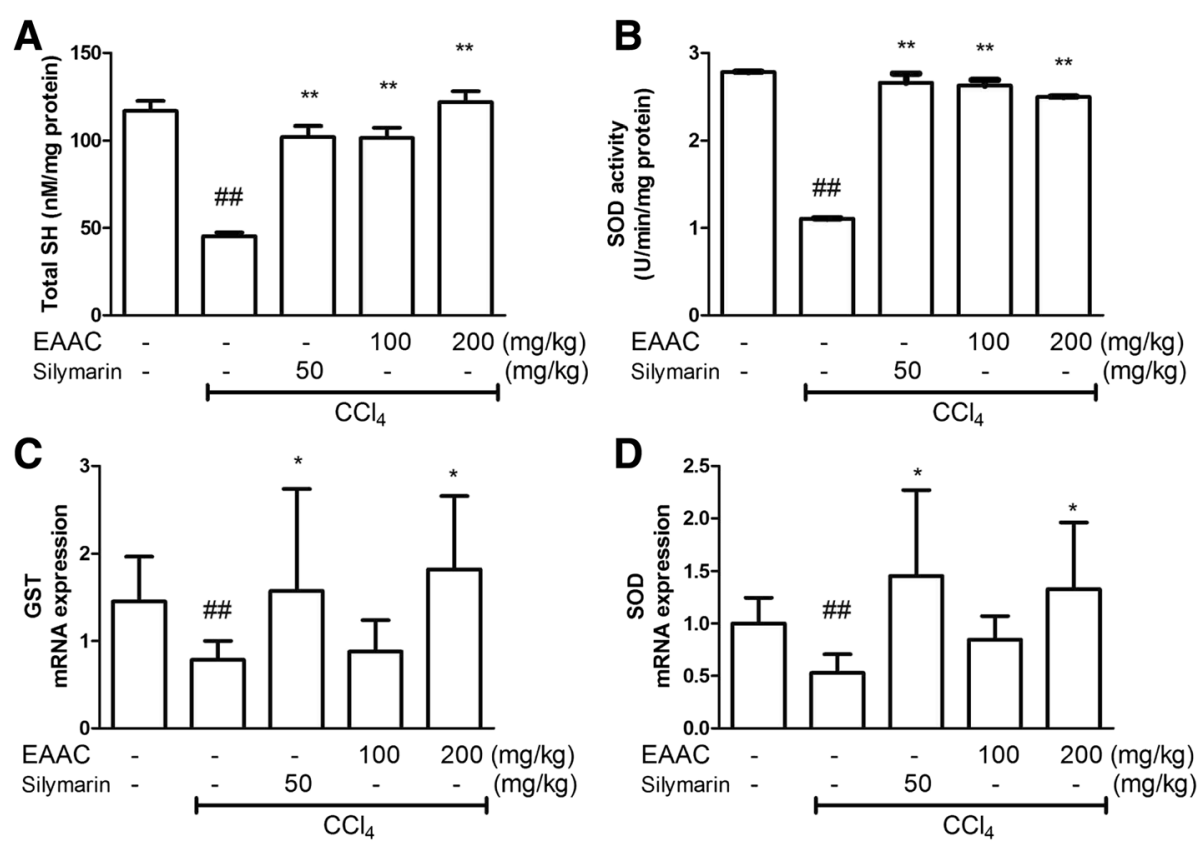

Fig. 6 Effect of EAAC treatment on total SH levels, SOD activity and anti-oxidative mRNA gene levels in rat liver. Liver tissue was homogenized and centrifuged. After centrifuged, supernatant was collected to investigate (a) total SH level and (b) SOD activity. For gene expression analysis, liver tissue was homogenized and lysed with Trisure to isolate mRNA. After CDNA synthesized, real-time PCR was conducted to investigate mRNA expression level. c GST expression level and (d) SOD expression level. \#\# shows statistically significnat difference at $p<0.01$ from the untreated group. * shows statistically significant differences at $p<0.05$ from the $\mathrm{CCl}_{4}$ group and ** at $p<0.01$

\section{CYP2E1}

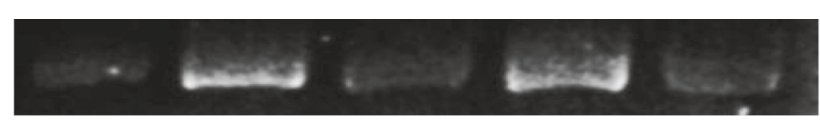

GAPDH
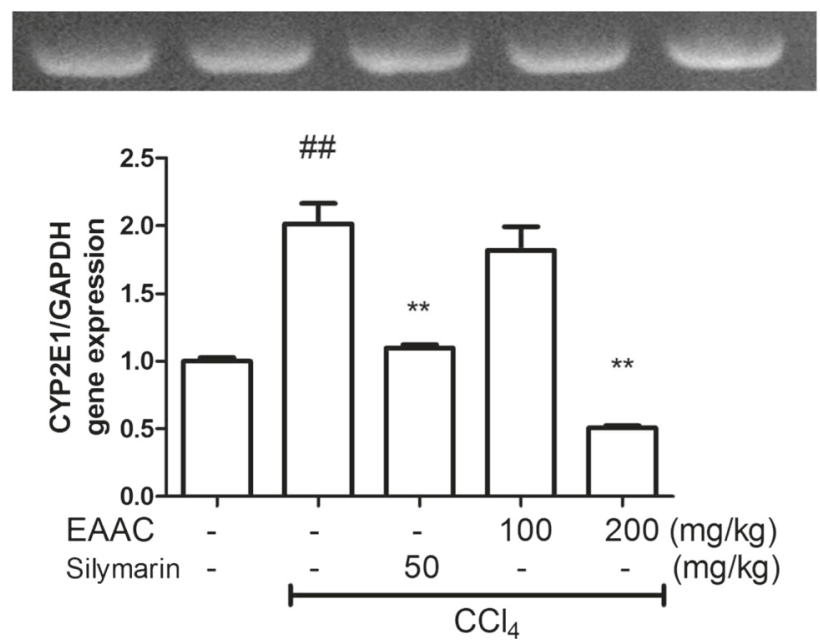

Fig. 7 Effect of EAAC treatment on CYP2E1 mRNA levels in rat liver. Liver tissue was homogenized and lysed with Trisure to isolate mRNA. After CDNA synthesized, both conventional PCR and real-time PCR was conducted to investigate mRNA expression level. The result of conventional PCR (CYP2E1 and GAPDH) was illuminated by gel electrophoresis. "\# shows statistically significnat difference at $p<0.01$ from the untreated group. * shows statistically significant differences at $p<0.05$ from the $\mathrm{CCl}_{4}$ group and ${ }^{* *}$ at $p<0.01$ 
and ALP in liver tissue that displayed protection against $\mathrm{CCl}_{4}$-induced degeneration. The decrease levels of these serum enzymes correlates with fewer necrotic lesions or histopathological injury, and lipid peroxidation in liver tissue [12, 47]. Moreover, induction of phase II enzymes including GSH, GST, and SOD are important in the balance between oxidative stress and antioxidation in a $\mathrm{CCl}_{4}$-induced acute liver injury model [48]. The present results show that exposure to $\mathrm{CCl}_{4}$ caused significant increases in serum ALT, AST, and ALP due to hepatic damage in rat liver. However, administration of $100 \mathrm{mg} /$ $\mathrm{kg}$ and $200 \mathrm{mg} / \mathrm{kg}$ body weight EAAC markedly restored liver physiology, which might be due to the phenolic compounds and total flavonoids. Furthermore, treatment with EAAC increased several phase II enzymes including total $\mathrm{SH}, \mathrm{GST}$, and SOD, which were reduced by $\mathrm{CCl}_{4}$, likely due to the antioxidant properties of EAAC.

CYP2E1, the most important hepatic cytochrome P450 isoform, is a $\mathrm{CCl}_{4}$ converting enzyme that catalyzes production of trichloromethyl free radicals in the liver [15, 49]. The liver is organ that is clearly influenced by CYP2E1, therefore, downregulation of CYP2E1 was expected by decrease of trichloromethyl free radical formation and reduced liver damage, inducing hepatocyte necrosis and hepatocellular injury [50]. In this study, the treatment of rats with $\mathrm{CCl}_{4}$ led to a significant overexpression of the CYP2E1 gene compared to control rats. However, treatment with $100 \mathrm{mg} / \mathrm{kg}$ and $200 \mathrm{mg} / \mathrm{kg}$ body weight EAAC significantly reduced CYP2E1 production. Therefore, it is suggested that $A$. cardamomum has valuable therapeutic potential for liver disease caused by CYP2E1 expression by decreasing CYP2E1 expression in liver.

\section{Conclusion}

The present study clearly demonstrates for the first time the hepatoprotective effect of EAAC against $\mathrm{CCl}_{4}$-induced acute liver injury. EAAC treatment significantly alleviated oxidative damage and lipid oxidation through its antioxidant properties. In addition, EAAC downregulated CYP2E1 on hepatotoxic events, comparable to the effect of silymarin in liver tissue. These findings suggest that $A$. cardamomum could be therapeutic as a traditional medicine in acute liver injury models.

\section{Ethics approval and consent to participate}

Present work was approved by the Ethics Committee at the Dongguk University, and all experiments were performed in accordance with the guidelines of the National Animal Care and Use Committee.

\section{Consent for publication}

Not applicable.

\section{Availability of data and materials}

The datasets supporting the conclusions of this article are presented in this main paper.

\begin{abstract}
Abbreviations
ALP: alkaline phosphatase; BHT: butylated hydroxytoluene;

$\mathrm{CCl}_{3}$ : trichloromethyl radicals; $\mathrm{CCl}_{4}$ : carbon tetrachloride; CYP450: cytochrome

P450; DMEM: Dulbecco's modified eagle medium; DMSO: dimethyl sulfoxide; DPBS: Dulbecco's phosphate buffered saline; DPPH: 2.2-Diphenyl-1-picryl hydrazyl; DTNB: 2-nitrobenzoic acid; EAAC: ethyl acetate fraction from A. cardamomum; FBS: fetal bovine serum; GOT: glutamic oxaloacetic transaminase; GPT: glutamic pyruvic transaminase; GSH: total glutathione; GST: glutathione S-transferase; H\&E: hematoxylin-eosin;

MDA: malondialdehyde; NBT: nitrobluetetrazolium; O.D: optical density; ORO: Oil red O; ROS: reactive oxygen species; RT-PCR: real-time polymerase chain reaction; SD: standard deviation; SOD: superoxide dismutase; TBA: 2thiobarbituric acid; TCDD: 2,3,7,8-tetrachlorodibenzo-p-dioxin.
\end{abstract}

\section{Competing interests}

The authors declare that they have no competing interests.

\section{Authors' contributions}

LDW, KH, PJY, KJE, MJY, PSD, and PWH conceived and designed the experiments. LDW performed the animal surgery, antioxidant properties, quantitative assay, and generated the figures. KH also performed the animal surgery and analyzed the data. PJY was determined reverse transcriptasepolymerase chain reaction in animal tissue. KJE, MJY and PSD analyzed the data and wrote the manuscript. PWH supervised the project and contributed to the final draft of the paper. All authors read and approved the final manuscript.

\section{Acknowledgments}

This work was supported by the Dongguk University Research Fund of 2015.

\section{Funding}

The authors declare that they have received no funding for the research reported.

\section{Author details}

'Department of Pathology, College of Korean Medicine, Dongguk University, Dongguk-Ro 32, Goyang 10326, Republic of Korea. ${ }^{2}$ Department of Diagnostics, College of Korean Medicine, Dongguk University, Dongguk-Ro 32, Goyang 10326, Republic of Korea. ${ }^{3}$ Department of Acupuncture and Meridian, College of Korean Medicine, Dongguk University, Dongguk-Ro 32, Goyang 10326, Republic of Korea. ${ }^{4}$ Department of Prescription, College of Korean Medicine, Dongguk University, Dongguk-Ro 32, Goyang 10326, Republic of Korea.

Received: 20 November 2015 Accepted: 13 May 2016

Published online: 31 May 2016

\section{References}

1. Zhu R, Wang Y, Zhang L, Guo Q. Oxidative stress and liver disease. Hepatol Res. 2012;42(8):741-9.

2. Casas-Grajales S, Muriel P. Antioxidants in liver health. World I Gastrointest Pharmacol Ther. 2015;6(3):59-72.

3. Byass P. The global burden of liver disease: a challenge for methods and for public health. BMC Med. 2014;12:159.

4. Betteridge DJ. What is oxidative stress? Metabolism. 2000;49(2 Suppl 1):3-8.

5. Poli G, Parola M. Oxidative damage and fibrogenesis. Free Radic Biol Med. 1997;22(1-2):287-305.

6. Parola M, Robino G. Oxidative stress-related molecules and liver fibrosis. J Hepatol. 2001;35(2):297-306.

7. Abdulaziz Bardi D, Halabi MF, Hassandarvish P, Rouhollahi E, Paydar M, Moghadamtousi SZ, Al-Wajeeh NS, Ablat A, Abdullah NA, Abdulla MA. Andrographis paniculata leaf extract prevents thioacetamide-induced liver cirrhosis in rats. PLoS One. 2014;9(10):e109424.

8. Salama SM, Abdulla MA, AIRashdi AS, Ismail S, Alkiyumi SS, Golbabapour S. Hepatoprotective effect of ethanolic extract of Curcuma longa on thioacetamide induced liver cirrhosis in rats. BMC Complement Altern Med. 2013;13:56. 
9. Noh JR, Gang GT, Kim YH, Yang KJ, Hwang JH, Lee HS, Oh WK, Song KS, Lee $\mathrm{CH}$. Antioxidant effects of the chestnut (Castanea crenata) inner shell extract in t-BHP-treated HepG2 cells, and CCl4- and high-fat diet-treated mice. Food Chem Toxicol. 2010;48(11):3177-83.

10. Valko M, Leibfritz D, Moncol J, Cronin MT, Mazur M, Telser J. Free radicals and antioxidants in normal physiological functions and human disease. Int J Biochem Cell Biol. 2007;39(1):44-84

11. Muriel P. Role of free radicals in liver diseases. Hepatol Int. 2009;3(4):526-36.

12. Sahreen S, Khan MR, Khan RA. Hepatoprotective effects of methanol extract of Carissa opaca leaves on CCl4-induced damage in rat. BMC Complement Altern Med. 2011;11:48

13. Recknagel RO, Glende Jr EA, Dolak JA, Waller RL. Mechanisms of carbon tetrachloride toxicity. Pharmacol Ther. 1989;43(1):139-54.

14. Jeong SC, Kim SM, Jeong YT, Song CH. Hepatoprotective effect of water extract from Chrysanthemum indicum L. flower. Chin Med. 2013:8(1):7.

15. Tunon MJ, Alvarez M, Culebras JM, Gonzalez-Gallego J. An overview of animal models for investigating the pathogenesis and therapeutic strategies in acute hepatic failure. World J Gastroenterol. 2009;15(25):3086-98.

16. Bhadauria M, Nirala SK, Shukla S. Multiple treatment of propolis extract ameliorates carbon tetrachloride induced liver injury in rats. Food Chem Toxicol. 2008:46(8):2703-12.

17. Nebert DW, Nelson DR, Coon MJ, Estabrook RW, Feyereisen R, Fujii-Kuriyama Y, Gonzalez FJ, Guengerich FP, Gunsalus IC, Johnson EF, et al. The P450 superfamily: update on new sequences, gene mapping, and recommended nomenclature. DNA Cell Biol. 1991;10(1):1-14.

18. Anzenbacher P, Anzenbacherova E. Cytochromes P450 and metabolism of xenobiotics. Cell Mol Life Sci. 2001;58(5-6):737-47.

19. Koop DR. Oxidative and reductive metabolism by cytochrome P450 2E1. FASEB J. 1992;6(2):724-30.

20. Dai N, Zou Y, Zhu L, Wang HF, Dai MG. Antioxidant properties of proanthocyanidins attenuate carbon tetrachloride (CCl4)-induced steatosis and liver injury in rats via CYP2E1 regulation. J Med Food. 2014;17(6):663-9.

21. Abbas AT, El-Shitany NA, Shaala LA, Ali SS, Azhar El, Abdel-Dayem UA, Youssef DT. Red Sea suberea mollis sponge extract protects against CCl4induced acute liver injury in rats via an antioxidant mechanism. Evid Based Complement Alternat Med. 2014;2014:745606.

22. Akhter S, Rahman MA, Aklima J, Hasan MR, Chowdhury JM. Antioxidative role of Hatikana (Leea macrophylla Roxb.) partially improves the hepatic damage induced by CCl4 in Wistar albino rats. Biomed Res Int. 2015;2015:356729.

23. Heo J. Translated Dongeuibogam. 1st ed. Seoul: Bubinmunwha; 1999.

24. Park J, Jin K, Lee J, Kwon H, Kim B. Anti-oxidative and anti-obesity effects of Amomum Cardamomum L. extract. Korean J Microbio Biotechnol. 2014;42(3):249-57.

25. Lee DH, Kang SS, Chang IM, Mar W. Detection of anti-inflammatory agents from natural products as inhibitors of cyclooxygenase I and II. Nat Prod Sci. 1997:3(1):19-28

26. Kim JW. Pharmacognosy. 2nd ed. Paju: Dongmyungsa; 2013.

27. Aleksandar R, Isidora M, Nebojša P, Tatjana Ć, Saša V, Momir M. Antioxidant activity of rosemary (Rosmarinus officinalis L.) essential oil and its hepatoprotective potential. BMC Complement Altern Med. 2014;14:225.

28. Ogaly HA, Eltablawy NA, El-Behairy AM, El-Hindi $\mathrm{H}$, Abd Elsalam RM. Hepatoxyte growth factor mediates the antifibrogenic action of Ocimum bacilicum essential oil against $\mathrm{CCl}_{4}$-induced liver fibrosis in Rat. Molecules. 2015;20(8):13518-35

29. El-Deib KM, Ahmed NZ. Comparison of the effects of some essential oil as anti-inflammatory agents on the activities of lysosomal acid-hydrolases in Rat liver in-ivtro. Nat Sci. 2011;9(10):90-8.

30. Murata S, Ogawa K, Matsuzaka T, Chiba M, Nakayama K, Iwasaki K, et al. 1,8-Cineole ameliorates steatosis of pten liver specific KO mice via Akt inctivation. Int J Mol Sci. 2015;16(6):12051-63.

31. Ciftci O, Ozdemir I, Tanyildizi S, Yildiz S, Oguzturk H. Antioxidative effects of curcumin, $\beta$-myrcene and 1,8-cineole against 2,3,7,8-tetrachlorodibenzo-pdioxin-induced oxidative stress in rats liver. Toxicol Ind Health. 2011;27(5): 447-53.

32. Vladimir-Knezevic S, Cvijanovic O, Blazekovic B, Kindl M, Stefan MB, Domitrovic R. Hepatoprotective effects of Micromeria croatica ethanolic extract against $\mathrm{CCl}_{4}$-induced liver injury in mice. BMC Complement Altern Med. 2015;15:233.

33. Amat N, Upur H, Blazekovic B. In vivo hepatoprotective activity of the aqueous extract of Artemisia absinthium L. against chemically and immunologically induced liver injuries in mice. J Ethnopharmacol. 2010;131(2):478-84.
34. Polshettiwar S, Ganjiwale R, Wadher S, Yeole P. Spectrophotometric estimation of total tannins in some ayurvedic eye drops. Indian J Pharm Sci. 2007;69(4):574

35. Lacikova L, Muselik J, Masterova I, Grancai D. Antioxidant activity and total phenols in different extracts of four Staphylea L. Species. Molecules. 2007; 12(1):98-102.

36. Zhishen J, Mengcheng T, Jianming $\mathrm{W}$. The determination of flavonoid contents in mulberry and their scavenging effects on superoxide radicals. Food Chem. 1999:64(4):555-9.

37. Gotoh N, Niki E. Rates of interactions of superoxide with vitamin E, vitamin $\mathrm{C}$ and related compounds as measured by chemiluminescence. Biochimica et Biophysica Acta (BBA)-General Subjects. 1992;1115(3):201-7.

38. de Groot H, Noll T. The crucial role of low steady state oxygen partial pressures in haloalkane free-radical-mediated lipid peroxidation. Possible implications in haloalkane liver injury. Biochem Pharmacol. 1986;35(1):15-9.

39. Sedlak J, Lindsay RH. Estimation of total, protein-bound, and nonprotein sulfhydryl groups in tissue with Ellman's reagent. Anal Biochem. 1968;25:192-205.

40. Takahashi M, Ushijima T, Ozaki Y. Changes in hepatic superoxide dismutase and xanthine oxidase activity in mice infected with Salmonella typhimurium and Pseudomonas aeruginosa. J Med Microbiol. 1988;26(4):281-4.

41. Khan RA, Khan MR, Sahreen S. CCl4-induced hepatotoxicity: protective effect of rutin on p53, CYP2E1 and the antioxidative status in rat. BMC Complement Altern Med. 2012;12:178.

42. Tirkey N, Pilkhwal S, Kuhad A, Chopra K. Hesperidin, a citrus bioflavonoid, decreases the oxidative stress produced by carbon tetrachloride in rat liver and kidney. BMC Pharmacol. 2005:5(1):2.

43. Bak M-J, Jun M, Jeong W-S. Antioxidant and hepatoprotective effects of the red ginseng essential oil in $\mathrm{H} 2 \mathrm{O} 2$-treated HepG2 cells and CCl4-treated mice. Int J Mol Sci. 2012;13(2):2314-30.

44. Das N, Islam ME, Jahan N, Islam MS, Khan A, Islam MR, Parvin MS. Antioxidant activities of ethanol extracts and fractions of Crescentia cujete leaves and stem bark and the involvement of phenolic compounds. BMC Complement Altern Med. 2014;14:45

45. Tenkerian C, El-Sibai M, Daher CF, Mroueh M. Hepatoprotective, antioxidant, and anticancer effects of the tragopogon porrifolius methanolic extract Evid Based Complement Alternat Med. 2015;2015:161720.

46. Fu Y, Zheng S, Lin J, Ryerse J, Chen A. Curcumin protects the rat liver from CCl4-caused injury and fibrogenesis by attenuating oxidative stress and suppressing inflammation. Mol Pharmacol. 2008;73(2):399-409.

47. Nabeshima Y, Tazuma S, Kanno K, Hyogo H, Iwai M, Horiuchi M, Chayama K. Anti-fibrogenic function of angiotensin II type 2 receptor in $\mathrm{CCl} 4$-induced liver fibrosis. Biochem Biophys Res Commun. 2006;346(3):658-64.

48. Castro JA, De Ferreyra EC, De Castro CR, De Fenos OM, Sasame H, Gillette $J R$. Prevention of carbon tetrachloride-induced necrosis by inhibitors of drug metabolism-further studies on their mechanism of action. Biochem Pharmacol. 1974:23(2):295-302.

49. Kathirvel $E$, Chen P, Morgan K, French SW, Morgan TR. Oxidative stress and regulation of anti-oxidant enzymes in cytochrome P4502E1 transgenic mouse model of non-alcoholic fatty liver. J Gastroenterol Hepatol. 2010; 25(6):1136-43.

50. Brady JF, Xiao F, Wang MH, Li Y, Ning SM, Gapac JM, Yang CS. Effects of disulfiram on hepatic P450lIE1, other microsomal enzymes, and hepatotoxicity in rats. Toxicol Appl Pharmacol. 1991;108(2):366-73.

\section{Submit your next manuscript to BioMed Central and we will help you at every step:}

- We accept pre-submission inquiries

- Our selector tool helps you to find the most relevant journal

- We provide round the clock customer support

- Convenient online submission

- Thorough peer review

- Inclusion in PubMed and all major indexing services

- Maximum visibility for your research

Submit your manuscript at www.biomedcentral.com/submit 